\title{
Primary dystonia, DYT13 type
}

INSERM

\section{Source}

INSERM. (1999). Orphanet: an online rare disease and orphan drug data base. Primary

dystonia, DYT 13 type. ORPHA:98807

DYT 13 type primary dystonia is characterized by focal or segmental dystonia with cranial, cervical, or upper limb involvement. 